\title{
Multi-element soil analysis: an assessment of its potential as an aid to archaeological interpretation.
}

Clare A. Wilson and Donald A. Davidson

School of Biological and Environmental Science, University of Stirling, Stirling, Scotland, UK, FK9 4LA, c.a.wilson@stir.ac.uk.

Malcolm S. Cresser

Environment Department, University of York, Heslington, York, UK, YO10 5DD

Multi-element soil analysis is now an established technique in archaeology. It has been used to locate archaeological sites and define the extent of human activity beyond the structural remains, and to aid interpretation of space use in and around archaeological remains. This study aimed to evaluate the consistency of these soil element signatures between sites and hence their potential usefulness in archaeological studies. Known contexts on abandoned farms across the UK were sampled to test the relationships between element concentrations and known functional area and to assess inter-site variability. The results clearly show that there are significant differences in the soil chemistry of contrasting functional areas, particularly for $\mathrm{Ba}, \mathrm{Ca}, \mathrm{P}, \mathrm{Zn}, \mathrm{Cu}, \mathrm{Sr}$ and $\mathrm{Pb}$. Despite significant site specific effects, which appear to reflect individual anthropogenic practices rather than geological influences, there is sufficient similarity in the pattern of element enhancement to allow reliable interpretation of former function using discriminant models. Relating these enhancements to precise soil inputs, however, is 
more problematic because many important soil inputs do not contain distinct element fingerprints and because there is mixing of materials within the soil. There is also a suggestion that charcoal and bone play an important role in both the loading and postdepositional retention of $\mathrm{Ca}, \mathrm{Sr}, \mathrm{P}, \mathrm{Zn}$, and $\mathrm{Cu}$ and thus may be significant in the formation of soil element concentration patterns.

Keywords: MULTI-ELEMENT SOIL ANALYSIS, ICP-AES, FUNCTIONAL AREAS, ABANDONED FARMS, ETHNOGRAPHIC STUDY, DISCRIMINANT ANALYSIS.

\section{Introduction}

Multi-element analytical techniques such as ICP-AES, ICP-MS and XRF have made quick and relatively cheap soil analysis available to archaeological investigations (for example Middleton and Price, 1996; Entwistle et al. 1998, 2000; Marwick, 2005). As a result, multi-element soil analysis has been used as a means of site prospection (Bintliff et al. 1992; Aston et al. 1998; Schlezinger and Howes, 2000; Eckel, et al. 2002) and to aid interpretation of former space use and activity within and around archaeological structures (Griffith, 1981; Middleton and Price, 1996; Parnell et al. 2002; Knudson et al. 2004; Sullivan and Kealhofer, 2004; Terry et al. 2004; Wells, 2004; Cook et al. 2005). These studies have shown that patterns of element concentration often reflect the known archaeology. At Piedras Negras in Guatemala (Parnell et al. 2002) elevated levels of barium $(\mathrm{Ba})$ phosphorus $(\mathrm{P})$, and manganese $(\mathrm{Mn})$ were found to be associated with areas of organic waste disposal whilst mercury $(\mathrm{Hg})$ and lead $(\mathrm{Pb})$ concentrations were associated with craft production areas. Entwistle et al. $(1998,2000)$ identified elevated 
concentrations of strontium $(\mathrm{Sr})$ and calcium $(\mathrm{Ca})$ associated with field areas whilst concentrations of potassium $(\mathrm{K})$, rubidium $(\mathrm{Rb})$ and thorium $(\mathrm{Th})$ were reliable indicators of settlement on former crofts (small farms) in the Isle of Skye.

Interpretation of element concentration patterns in archaeological soils is problematic because of the complexity of site use history and the effects of post-depositional soil processes. Many human activities, including food preparation, hearths, middening and manuring, craft working and industrial processes, can add element loadings to cultivated soils, occupation deposits and floor layers. However, a host of natural and anthropogenic processes may affect total soil concentrations. Background variation linked to differences in geology, soils, and hydrology can result in patterns of element concentration unconnected to the archaeology. Post-depositional soil forming processes such as podzolisation, leaching and gleying may influence the retention and redistribution of anthropogenic element loadings in the soil. For example, Ottaway and Matthews (1988) noted a distortion in results due to leaching of $\mathrm{Ca}$ and $\mathrm{Mg}$ at a tell site in Yugoslavia, and Pierce et al. (1998) identified possible post-depositional alteration of fuel ash signatures. Materials brought on to a site often become mixed and following site abandonment, the re-use of structures, decay of buildings, and later anthropogenic additions (e.g. lime, fertilisers and atmospheric deposition) can add their particular element loadings. There is also potential for development of secondary elemental patterning linked to previous site activity, but not directly reflecting the geochemistry of the inputs to the soil. Such patterns can develop when former human activity has altered physical, biological and 
chemical soil properties, affecting the retention and distribution of natural and anthropogenic element loadings.

Despite the complex nature of soil geochemical loadings, there have been few studies to validate the use of multi-element soil analysis in archaeological contexts. Recent ethnographic studies have provided much needed data and confirmed that soils and floor layers from different functional areas often have different chemical signatures (e.g. Middleton and Price, 1996; Pierce et al. 1998; Fernández et al. 2002; Knudson et al. 2004; Terry et al. 2004; Wilson et al. 2005). Some of these studies have compared modern with ancient soil signatures (e.g. Terry et al. 2004) and have identified both similarities and discrepancies in geochemical patterning.

This study aims to evaluate through the use of context-known material the extent to which soil element concentration reflects past human activities. The hypotheses are 1) that different functional areas have characteristic geochemical signatures and these signatures are broadly consistent between sites. 2) Input materials have characteristic geochemical signatures and these are broadly consistent between sites. 3) The geochemistry of soils and floor layers can be related to the geochemistry of known former inputs to these soils. This anthropogenic study of known Post-Medieval farm sites is designed to evaluate the extent to which soil element concentrations reflect former occupation processes and hence how reliable they may be in aiding interpretation of archaeological activity areas. 


\section{Methodology}

Study sites and sampling

Six small farms (ca. 5 hectares cultivated land) abandoned between the late 1800s and 1940 were chosen to represent a range of broadly comparable, known study sites spread throughout Scotland, England and Wales. These sites are: Olligarth, Papa Stour, Shetland; Grumby, Sutherland; Balnreich, Perthshire; Auchindrain, Argyll; Far House, North Yorkshire; Cwm Eunant, Powys. A summary of site characteristics including geology, construction, fuel materials, and agricultural practice is presented in Table 1.

The study sites represent a range of contrasting geology, however care was taken to make the study sites as comparable as possible in all other respects though inevitably there are differences in the age of abandonment, construction and land management of the six sites. The townships of Auchindrain and Balnreich are the earliest abandonments (late $19^{\text {th }} \mathrm{C}$ ) and have the simplest construction with clay mortar, rather than lime. Both sites are dominated by spodosols and histosols formed in schist derived tills. The sites of Grumby in Sutherland and Olligarth, Papa Stour, Shetland were both abandoned in 1940. The stone walls of both farm houses were originally dry clay mortared, however lime has been used to patch the walls in the house (particularly the hearth) at Grumby and the internal and external walls of the house at Olligarth were finished with a shell rich plaster. Both were originally thatched, though at Olligarth this had been replaced on the house and byre by tarred roofing felt. The geology is rhyolite at Olligarth, and gneiss and granite at Grumby. The remaining two sites - Far House, North Yorkshire, and Cwm 
Eunant, Powys - were small tenant farms with lime mortar contstruction, abandoned in 1938 and 1918 respectively.

At each farm samples were taken from the hearth, house (kitchen), byre, midden, garden, arable fields, grazed out-fields and off-site reference soils where present. Auger samples were taken from the top soils (upper $0-20 \mathrm{~cm}$ or less) in the buildings and fields across 1 $\mathrm{m}$ grids. Test pits $0.7 \mathrm{~m} \times 0.7 \mathrm{~m}$ in each context allowed profile description following the Soil Survey of England and Wales (Hodgson, 1976) and sampling at a $20 \mathrm{~cm}$ depth interval. In the buildings, the test pits were taken down to the final floor layers, which were also sampled. Where stone or cobble floors were present samples were taken from the gaps between the stones, and from the hearths samples were taken from the surface of the hearth stone. At least five replicate samples were taken from each profile depth. Reference materials representing the range of potential inputs to the site were collected locally from around each site. At least 3 examples of each material were collected at each site where they were represented. These include animal dung, peat, wood, coal, bracken, bone, plaster, and mortar. The range of reference materials was biased by availability; this favoured organic materials still available locally, and construction materials such as plaster or mortar that were present on standing walls. Due to differences in local conditions and site history there is, in some cases, only limited overlap between reference materials for the six sites. Dung materials were collected from grass fed, organically reared animals. In total 832 soil samples and 145 reference material samples were collected and analysed. 


\section{Soil analysis}

Soils were oven-dried and sieved through stainless steel sieves to $<2 \mathrm{~mm}$. Air-dried reference materials were ground in a steel mill and sieved. Five grams of soil / reference material were digested in concentrated Nitric Acid (Aristar) at $120^{\circ} \mathrm{C}$ for one hour then filtered through Whatman No 2 papers. The filtrate was made to $100 \mathrm{ml}$ volume using deionised water $\left(<18 \Omega\right.$ purity). Diluted samples $\left(5 \% \mathrm{HNO}_{3}\right.$ matrix $)$ were analysed using a Perkin Elmer 3300RL ICP-AES and a sub-set of samples were analysed using a Surrey Research Instrument ICP-MS $\left(2 \% \mathrm{HNO}_{3}\right.$ matrix $)$. Correlation between the results of these two methods was good with R square values of between $.999(\mathrm{Cu})$ and $.901(\mathrm{Eu})$, hence ICP-AES was used in subsequent analysis. Loss-on ignition $\left(405^{\circ} \mathrm{C}\right)$ was determined for all soil and reference material samples, and soil $\mathrm{pH}$ (1:5 soil: water) for all soil samples. A strong acid digest was used rather than the mild acid digest often recommended (e.g. Middleton, 2004) based on the findings of sequential extractions published in Wilson et al. (2006a) that a significant proportion of the anthropogenic signal is held within the more resistant soil fractions.

\section{Microanalysis}

Undisturbed Kubiena samples were collected from the hearth, byre, garden, arable fields, and grazed fields at Olligarth. The samples were air dried, impregnated with epoxy resin and the cured blocks were cut, bonded to glass slides and lapped to produce thin sections with a nominal thickness of $30 \mu \mathrm{m}$. This procedure followed standard methods used at Stirling University (http://www.thin.stir.ac.uk/methods.html). Thin sections were described using an Olympus BX-50 petrological microscope following the terminology 
of Bullock et al. (1985). Carbon-coated samples were analysed using a Cameca SX-100 SEM-WDX system. Relative element distributions were mapped across areas of interest sized $1 \mathrm{~cm} \times 1 \mathrm{~cm}$ (resolution $20 \mu \mathrm{m}$ ) or $1.5 \mathrm{~mm} \times 1.5 \mathrm{~mm}$ (resolution of $3 \mu \mathrm{m}$ ) using 15 $\mathrm{kV}$ accelerating voltage and $200 \mathrm{nA}$ beam current.

\section{Data analysis}

Element concentration data were transformed using a natural log transform to approximate a normal distribution. The data set was inspected for extreme outliers (Quartiles +/- $3 \mathrm{x}$ interquartile range) and where necessary these were removed. Analysis of the data showed that despite strong correlation between the geochemistry of the topsoils and associated floor layers, the best results were obtained from the analysis of floor sample data from the buildings and topsoil data from the fields; this data was used in the subsequent analyses. Each site was analysed separately to ascertain patterns of element concentration and significant differences between functional areas. GLM ANOVA with Tamhane's T2 post-hoc tests were used to do this in SPSS ver. 13.0 for Windows. For each site a step-wise discriminant model for function based on soil element concentrations was developed using functional area as the discriminator. To check for multivariate normality histograms of frequency distribution were plotted. Four sites (Balnreich and Auchindrain lacked a midden or hearth and were omitted to avoid bias) were analysed together in a combined model to assess between site similarities in patterns of element soil concentrations. Because of differences in background soil element concentrations and in the level of enhancement between sites, z scores were used 
to standardise data and the analysis was repeated. However, this approach was found to hide significant between site differences and resulted in little improvement to the models.

\section{Results}

Site differences

Significant differences $(p<0.05)$ in all element concentrations were identified between the off-site reference soils at the six farm sites (Table 2). Background concentrations of $\mathrm{Co}$, for example, varied between $0.29 \mathrm{mg} \mathrm{kg}^{-1}$ at Olligarth and $16 \mathrm{mg} \mathrm{kg}^{-1}$ at $\mathrm{Cwm}$ Eunant. Significant site differences were also identified in the on-site (house, hearth and byre areas) element concentrations for each element analysed. However, the only element for which high background (reference soil) concentrations are reflected on-site is $\mathrm{Pb}$ with high concentrations in both the reference and on-site soils at Cwm Eunant and Far House (Table 3).

\section{Functional area differences}

The results reveal differences in element concentrations between the functional areas at all six sites (Table 3). Compared to the reference and unamended outfield soils, those in and around the buildings showed levels of enhancement of up to $120 \mathrm{x}$ for $\mathrm{Ca}, 37 \mathrm{x}$ for $\mathrm{Pb}$, and $43 \mathrm{x}$ for $\mathrm{Zn}$. The nature and significance of this variation is described by the application of GLM ANOVA (Table 4). This shows how concentrations of Ti, Ni and Fe are strongly influenced by site, whilst $\mathrm{Ca}, \mathrm{Zn}$, and $\mathrm{P}$ show weaker site effects and are more strongly influenced by functional area. Site $\mathrm{x}$ functional area effects are also significant for each element, hence the pattern of element enhancement between different 
functional areas may also have a strong site specific effect. However, generalised patterns of element enhancement did emerge (Figure 1) and can be summarised as follows.

The highest concentrations of $\mathrm{Ca}$ tend to occur in the hearth closely followed by the house. Overall there tends to be little enhancement of $\mathrm{Ca}$ in the arable fields and garden relative to the out-fields and reference soils The highest concentrations of $\mathrm{P}$ tend to occur in the byres, though concentrations in the hearth and house, and midden are also significantly higher than in outfield and reference soils. A similar pattern is seen for Ba and $\mathrm{Sr}$. The highest concentrations of $\mathrm{Pb}$ occur in the hearth and house, elevated concentrations of $\mathrm{Pb}$ are also associated with the midden, byre, and garden. However, there is no significant enhancement of $\mathrm{Pb}$ in the arable fields. With the exception of Grumby (high $\mathrm{Zn}$ in the house), the highest $\mathrm{Zn}$ concentrations are also found in the hearth; the house, byre and midden also contain significantly enhanced concentrations of $\mathrm{Zn}$, as to a lesser extent do the gardens. The lowest concentrations are in the reference soils and there is evidence of moderate $\mathrm{Zn}$ enhancement in the arable fields as well.

Results from the stepwise discriminant analysis clearly differentiate between functional areas irrespective of site. A model was produced using two-thirds data from each functional area; this model was tested using data not used in the creation of the model. The success rate for context prediction was $75.4 \%$ out of a total of eight functional areas. The first three discriminant functions account for $92.5 \%$ of the variance, and correlate strongly with the suite of routinely enhanced elements (Table 5). Function 1 accounts for $61 \%$ of the chemical variation and is positively correlated with concentrations of $\mathrm{Ca}, \mathrm{Sr}$ 
and $\mathrm{Zn}$; this function tends to separate the domestic contexts (hearth, house, byre and midden) from the fields (infield and outfield) and reference samples. Function 2 accounts for $23 \%$ of the total variation and correlates positively with $\mathrm{Na}$ and negatively with concentrations of $\mathrm{P}, \mathrm{Mn}$ and $\mathrm{Ba}$. This function may be linked to the effects of manure as the unmanured reference samples, outfields, house and hearth have higher discriminant scores than the manured byre, midden, kailyard and infield samples (Table 6).

\section{Reference materials}

Table 7 shows the results of ANOVA for the reference input materials and reveals that bracken, dung and turf chemistry is significantly influenced by site effects for more elements than lime mortar and peat. However, as would be expected from the disparate materials analysed, the between site differences are small compared to the between material differences (Table 8). Figure 2 illustrates the mean elemental composition of some of the most common reference materials. This shows charcoal that was manually extracted from the soils as an important source of $\mathrm{Ca}, \mathrm{Ba}, \mathrm{Cu}, \mathrm{Sr}, \mathrm{Zn}, \mathrm{P}$, and $\mathrm{Pb}$. However, a sample of fresh charcoal from Cwm Eunant contained much lower concentrations of $\mathrm{Ba}(578 \mathrm{mg} / \mathrm{kg}), \mathrm{Zn}(113 \mathrm{mg} / \mathrm{kg})$ and $\mathrm{Pb}(5.77 \mathrm{mg} / \mathrm{kg})$. The bone samples were all taken from the soil surface and contain high concentrations of $\mathrm{Ca}$ and $\mathrm{P}$, moderate amounts of $\mathrm{Ba}$ and $\mathrm{Sr}$, and only low concentrations of $\mathrm{Cu}\left(2.31 \mathrm{mg} \mathrm{kg}^{-1}\right), \mathrm{Zn}$ (101 $\mathrm{mg} \mathrm{kg}^{-1}$ ) and $\mathrm{Pb}$ (below detection limits). Lime mortar is a major source of $\mathrm{Ca}$, and also contains moderate amounts of $\mathrm{Sr}$ and $\mathrm{Pb}$. Peat, turf and wood contain moderate amounts of $\mathrm{Pb}$, whilst peat is also associated with moderate amounts of $\mathrm{Cu}, \mathrm{Sr}$, and $\mathrm{Ba}$. 
Microprobe analysis (SEM-WDX) of the soils at Olligarth revealed the relative distribution of elements within the soils, as summarised in Table 9. High concentrations of $\mathrm{Zn}$ and $\mathrm{Cu}$ are associated with mineral grains and bone fragments, Fe concentrations are associated with mineral grains and certain carbonised particles, and $\mathrm{P}$ and $\mathrm{Ca}$ are associated with bone and certain carbonised particles (Figure 3). The identification of carbonised particles was confirmed using C:O ratios following Davidson et al. (2006). Whilst some carbonised particles contained enhanced levels of $\mathrm{Fe}, \mathrm{Ca}$ and $\mathrm{P}$ others contained no detectable (detection limits typically ca. $100 \mathrm{mg} \mathrm{kg}^{-1}$ ) traces of these elements. The reason for this is unclear as no consistent link was found with black particle morphology or $\mathrm{C}: \mathrm{O}$ ratio.

\section{Discussion}

The results clearly demonstrate that multi-element analysis has the potential to discriminate between areas of different function on abandoned farm sites. On any one site any of the 29 analysed elements may show a pattern of enhancement that reflects the known patterns of use on the site. However, interpretation of these signatures requires consistency between sites and discernable links between the element chemistry of inputs to the soils and the geochemistry of the soils themselves.

The farm sites were chosen to represent areas of contrasting geology, as a result the background element concentrations (as shown by the reference soils) differ markedly. Significant site differences were also identified from soils in and around the abandoned farms for all elements. However, with the exception of $\mathrm{Pb}$, there is no correlation 
between background concentrations and within building concentrations at the different sites, suggesting that anthropogenic factors rather than background geology are responsible for the pattern of enhancement.

Despite site differences, functional area effects are also highly significant especially regarding concentrations of $\mathrm{Ca}, \mathrm{P}, \mathrm{Ba}, \mathrm{Pb}, \mathrm{Cu}, \mathrm{Sr}$, and $\mathrm{Zn}$. This is particularly interesting as many previous archaeological multi-element studies have also found significant patterning in these elements coincident with archaeological structures (Table 10). Site effects appear to be dominant for elements such as $\mathrm{Ti}, \mathrm{Ni}$, and $\mathrm{Fe}$ hence these elements are less useful for functional area interpretation on abandoned farm sites.

The generalised pattern of enhancement on the farm sites is high concentrations of a large suite of elements, with the exception of $\mathrm{P}$, to be associated with the hearth. A similar suite of enhanced elements is associated with house soils, although at slightly lower levels, and the byres tend to contain slightly lower levels again though $\mathrm{P}$ is often found in the highest concentration in the byre. Discriminant analysis shows that these functional area differences are sufficient to provide accurate predictions irrespective of site. Independently tested data from four study sites was successfully assigned to one of eight functional areas in $75 \%$ of cases using a combined model. Again, concentrations of $\mathrm{Ca}, \mathrm{P}$, $\mathrm{Zn}, \mathrm{Sr}, \mathrm{Ba}$, and also $\mathrm{Mn}$ were found to be significant in differentiating between functional areas. However, models that exclude one site are little better at predicting functional area in the excluded site than by chance alone. These results suggest that where known analogues exist it may be possible to provide interpretations of space use based on soil 
multi-element concentrations. Discriminant analysis also provides some evidence of two anthropogenic geochemical systems affecting these sites, the first linked to domestic structures and inputs, and the second to the effects of manuring. Correlation between floor layer and overburden chemistry supports the use of multi-element analysis as a prospection tool and topsoils may also have some value for interpretation of space use in buried sites.

As expected of a disparate group of reference input materials there are clear differences in their elemental compositions. Charcoal appears to be linked with a large suite of our key elements, however, this only applies to old charcoal extracted from the soil, fresh charcoal from the surface at Cwm Eunant does not show contain high concentrations of $\mathrm{Ba}, \mathrm{Zn}$, and $\mathrm{Pb}$ suggesting post-depositional uptake and concentration. The importance of charcoal for $\mathrm{Ca}, \mathrm{P}$, and $\mathrm{Fe}$ is highlighted by microprobe data, and a post-depositional role for bone in the retention of $\mathrm{Zn}$ and $\mathrm{Cu}$ is also suggested. Similar, post-depositional enrichment of bone with $\mathrm{Zn}$ and $\mathrm{Cu}$ has also been identified in the soils of the formerly inhabited Scottish island of St. Kilda (Davidson et al. 2007).

Although reference material chemistry is dominated by material type rather than site it is difficult to relate any one input to the geochemistry of the soils in the different functional areas. The correlation between input geochemistry and soil geochemistry tends to be generalised, for example, high P concentrations in the byre and midden, could be linked to high phosphorus concentrations in dung. High concentrations of all elements in the hearth could reflect the wide range of elements in fuel sources (turf, peat and coal) 
concentrated by combustion processes and possibly aided by the retention of elements liked to higher cation exchange capacities and the presence of charcoal. Other element patterns can be linked to known anthropogenic activities at specific sites. For example, high $\mathrm{Ca}$ and $\mathrm{Sr}$ concentrations at Cwm Eunant, Far House and to a lesser extent Grumby and Olligarth appear to be associated with local lime-based construction methods. However, finer detail of inputs and mixing of materials in the soil can be hard to interpret. The geochemistry of the site inputs are distinct, therefore, the multitude of sources, the widespread mixing and distribution of loadings across the sites and possible post-depostional alteration may all be partly responsible for these difficulties. Some success in identifying inputs and modelling the movement of material has been achieved using $\mathrm{Pb}$ isotope ratios and mixing equations (Wilson et al. 2006b). Isotope analysis highlighted the importance of fuel materials as a source of $\mathrm{Pb}$ at the abandoned croft of Olligarth, and the high multi-element concentrations in the hearths of all six farm sites in this study support the hypothesis that ash is an important loading. Occasional trace elements may be better at identifying inputs, for example, the concentrations of mercury (Hg) and $\mathrm{Pb}$ associated with craftworking at Piedras Negras (Parnell et al. 2002) and gold and rare earth elements at Cancuén (Cook et al. 2006), rather than the suite of generally enhanced elements identified here (Ba, $\mathrm{Ca}, \mathrm{Cu}, \mathrm{P}, \mathrm{Pb}, \mathrm{Sr}$ and $\mathrm{Zn}$ ) that are better at differentiating functional areas.

Results from microprobe analysis have demonstrated the importance of charcoal and bone to the enhanced concentrations of $\mathrm{Ca}, \mathrm{P}, \mathrm{Sr}, \mathrm{Zn}$, and $\mathrm{Cu}$. In part this is directly due to the composition of these materials but there is also the suggestion that bone and 
charcoal are important in the retention of these elements and that there may even be some post-depositional uptake. This has important implications for the interpretation of multielement data, particularly on older archaeological sites that will have been affected by post-depositional soil forming processes such as leaching, gleying, calcification, and podzolisation for hundreds or thousands of years. Wilson et al. (2006a) used sequential extraction to examine the partitioning of $\mathrm{Ca}, \mathrm{Zn}$ and $\mathrm{Pb}$ in the soils from Grumby. This study suggested that although a high proportion of calcium is held within the exchangeable fraction, a significant proportion of $\mathrm{Ca}, \mathrm{Zn}$, and $\mathrm{Pb}$ is associated within the more recalcitrant soil fractions. This suggests that these anthropogenic element signatures are relatively resistant and may persist in soil for relatively long periods of time. More research is needed to understand post-depositional cycling of anthropogenic element loadings in archaeological soils.

\section{Conclusions}

Concentrations of elements, particularly $\mathrm{Ca}, \mathrm{Ba}, \mathrm{Sr}, \mathrm{Zn}, \mathrm{P}$ and $\mathrm{Pb}$, do reflect patterns of former human activity on abandoned farm sites. This suite of elements is not only enhanced on abandoned farm sites, but has also been linked to functional areas in archaeological sites across the globe. In only the most general sense can their concentrations be linked to particular inputs. Microprobe analysis has raised the possibility that their retention in the soil is linked to charcoal and bone concentrations and that the patterns of enhancement seen in this study could in part be a secondary postdepositional effect. The implications of this ethnographic study of known functional contexts for the application of multi-element analysis more widely to archaeological sites 
are that soil element concentrations can correlate strongly with patterns of archaeological activity. Despite site by site differences related more closely to individual anthropogenic practices than geological background, there are broad similarities in the pattern of element enhancement across areas of similar function. This suggests that multi-element analysis can help interpret former function on archaeological sites, providing that data is available from relevant functional analogues. However, more work is required to understand the effects of post-depositional pedogenic cycling of anthropogenic element loadings.

\section{Acknowledgements}

This study was funded by the Natural Environment Research Council, UK (NER $\backslash A \backslash S \backslash 2001 \backslash 00996)$. Analytical time and help were provided by the NERC ICP facility and the NERC Microprobe facility, University of Manchester.

\section{References}

Aston, M.A., Martin, M.H., Jackson, A.W., 1998. The use of heavy metal soil analysis for archaeological surveying. Chemosphere 37, 465-477.

Bintliff, J.L., Davies, B., Gaffney, C., Snodgrass, A., Waters, A., 1992. Trace metal accumulations in soils on and around ancient settlements in Greece. Geoprospection in the Archaeological Landscape, Oxbow Monographs 17, Oxbow Books, Oxford, pp. 9-24. Bullock, P., Federoff, N., Jongerius, A., Stoops, G., Tursina, T., 1985. Handbook for soil thin section description. Waine Research Publications, Wolverhampton. 
Cook, D.E., Kovacevich, B., Beach, T., Bishop, R., 2006. Deciphering the inorganic chemical record of ancient human activity using ICP-MS: a reconnaissance study of late Classic soil floors at Cancuén, Guatemala. J. Archaeol. Sci. 33, 628-640.

Cook, S.R., Clarke, A.S., Fulford, M.G., 2005. Soil geochemistry and detection of early Roman precious metal and copper alloy working at the Roman town of Calleva Atrebatum (Silchester, Hampshire, UK). J. Archaeol. Sci. 32, 805-812.

da Costa, M.L., Kern, D.C., 1999. Geochemical signatures of tropical soils with archaeological black earth in the Amazon, Brazil. J. Geochem. Explor. 66, 369-385.

Davidson, D.A., Dercon G., Stewart, M., Watson, F., 2006. The legacy of past urban waste disposal on local soils. J. Archaeol. Sci. 33, 778-783.

Davidson, D.A., Wilson, C.A., Meharg, A., Stutter, C., Edwards, K.J., 2007. The legacy of past manuring practices on soil contamination in remote rural areas. Environ. Int. 33, 78-83.

Dunnell, R.C., 1993. Chemical origins of archaeological aerial signatures, in: Lewis A.J., Kelly G.G. (Eds.) Looking to the future with an eye on the past. Proceedings of the Annual ACSM/ASPRS convention, New Orleans, Volume 2, ASPRS/ACSM, pp. 66-75. Eckel, W.P., Rabinowitz, M.B., Foster, G.D., 2002. Investigation of unrecognized former secondary lead smelting sites: confirmation by historical sources and elemental ratios in soil. Environ. Pollution 117, 273-279.

Entwistle, J.A., Abrahams, P.W., Dodgshon, R.A., 1998. Multi-element analysis of soils from Scottish historical sites. Interpreting land-use history from the physical and geochemical analysis of soil. J. Archaeol. Sci. 25, 53-68. 
Entwistle, J.A., Dodgshon, R.A., Abrahams, P.W., 2000. An investigation of former landuse activity through the physical and chemical analysis of soils from the Isle of Lewis, Outer Hebrides. Archaeol. Prospect. 7, 171-188.

Fernández, F.G., Terry, R.E., Inomata, T., Eberl, M., 2002. An ethnoarchaeological study of chemical residues in the floors and soils of Q'eqchi' Maya houses at Las Pozas, Guatemala. Geoarchaeology 17, 487-519.

Griffith, M.A., 1981. A pedological investigation of an archaeological site in Ontario, Canada: use of chemical data to discriminate features of the Benson site. Geoderma 25, 27-34.

Hodgson, J.M., 1976. Soil survey field handbook. Soil Survey England and Wales; Harpenden, Technical Monograph No. 5.

James, P., 1999. Soil variability in the area of an archaeological site near Sparta, Greece. J. Archaeol. Sci. 26, 1273-1288.

Knudson, K.J., Frink, L, Hoffman, B.W., Price, T.D., 2004. Chemical characterization of Arctic soils: activity area analysis in contemporary Yup'ik fish camps using ICP-AES. J. Archaeol. Sci. 31, 443-456.

Konrad, V.A., Bonnichsen, R., Clay, V., 1983. Soil chemical identification of ten thousand years of prehistoric human activity areas at the Munsungun Lake Thoroughfare, Maine. J. Archaeol. Sci. 10, 13-28.

Kristiansen, S.M., 2001. Present-day soil distribution explained by prehistoric land-use: Podzol-Arensol variation in an ancient woodland in Denmark. Geoderma 103, 273-289. Lewis, R.J., Foss, J.E., Morris, M.W., Timpson, M.E., Stiles, C.A., 1993. Trace element analysis in pedo-archaeology studies, In: Foss, J.E., Timpson, Morris, M.W. (Eds.), 
Proceedings of the First International Conference on Pedo-Archaeology. University of Tennessee Press, pp. 81-88.

Linderholm, J., Lundberg, E., 1994. Chemical characterization of various archaeological soil samples using main and trace elements determined by Inductively Coupled Plasma Atomic Emission Spectrometry. J. Archaeol. Sci. 21, 303-314.

Marwick, B., 2005. Element concentrations and magnetic susceptibility of anthrosols: Indicators of prehistoric human occupation in the inland Pilbara, Western Australia. J. Archaeol. Sci. 32, 1357-1368.

Middleton, W.D., 2004. Identifying chemical activity residues on prehistoric house floors: a methodology and rationale for multi-elemental characterization of a mild acid extract of anthropogenic sediments. Archaeometry 46, 47-65.

Middleton, W.D., Price, T.D., 1996. Identification of activity areas by multi-element characterization of sediments from modern and archaeological house floors using inductively coupled plasma-atomic emission spectroscopy. J. Archaeol. Sci. 23, 673-687. Ottaway J.H., Matthews M.R., 1998. Trace element analysis of soil samples from a stratified archaeological site. Environ. Geochem. Health 10, 105-112. Parnell, J.J., Terry, R.E., Nelson, Z., 2002. Soil chemical analysis applied as an interpretive tool for ancient human activities in Piedras Negras, Guatemala. J. Archaeol. Sci. 29, 379-404.

Pierce, C., Adams, K.R., Stewart, J.D., 1998. Determining the fuel constituents of ancient hearth ash via ICP-AES analysis. J. Archaeol. Sci. 25, 493-503.

Schlezinger, D.R. Howes, B.L., 2000. Organic phosphorus and elemental ratios as indicators of prehistoric human occupation. J. Archaeol. Sci. 27, 479-492. 
Sullivan, K.A., Kealhofer, L., 2004. Identifying activity areas in archaeological soils from a colonial Virginia house lot using phytolith analysis and soil chemistry. J. Archaeol. Sci. 31, 1659-1673.

Terry, R.E., Fernández, F.G., Parnell, J.J., Inomata, T., 2004. The story in the floors: chemical signatures of ancient and modern Maya activities at Aguateca, Guatemala. J. Archaeol. Sci. 31, 1237-1250.

Wells, E.C., 2004. Investigating activity patterns in prehispanic plazas: weak acidextraction ICP-AES analysis of anthrosols at Classic period El Coyote, northwestern Honduras. Archaeometry 46, 67-84.

Wells, E.C., Terry, R.E., Parnell, J.J., Hardin P.J., Jackson, M.W., Houston, S.D., 2000. Chemical analyses of ancient anthrosols in residential areas at Piedras Negras, Guatemala. J. Archaeol. Sci. 27, 449-462.

Wilson, C.A., Bacon, J.R., Cresser, M.S., Davidson, D.A., 2006b. Lead isotope ratios as a means of sourcing anthropogenic lead in archaeological soils: a pilot study of an abandoned Shetland croft. Archaeometry 48, 501-509.

Wilson, C.A., Cresser, M.S., Davidson, D.A., 2006a. Sequential extraction of soils from abandoned farms: an investigation of the partitioning of anthropogenic element signatures of historic land use. J. Environ. Monitor. 8, 439-444. 
Wilson, C.A., Davidson, D.A., Cresser, M.S., 2005. An evaluation of multi-element analysis of historic soil contamination to differentiate space use and former function in and around abandoned farms. Holocene 15, 1094-1099. 
Table 1: Summary of site characteristics and history.

\begin{tabular}{|c|c|c|c|c|c|c|}
\hline & $\begin{array}{l}\text { Auchindrain } \\
\text { Argyll }\end{array}$ & $\begin{array}{l}\text { Balnreich } \\
\text { Perthshire }\end{array}$ & $\begin{array}{l}\text { Cwm Eunant } \\
\text { Powys }\end{array}$ & $\begin{array}{l}\text { Far House } \\
\text { N. Yorkshire }\end{array}$ & $\begin{array}{l}\text { Grumby } \\
\text { Sutherland }\end{array}$ & $\begin{array}{l}\text { Olligarth } \\
\text { Shetland }\end{array}$ \\
\hline Geology & Schist & $\begin{array}{l}\text { mica schist } \\
\text { and gabbro }\end{array}$ & Shale and slate & $\begin{array}{l}\text { Oolite and } \\
\text { sands }\end{array}$ & Gneiss & Rhyolite \\
\hline Soils & $\begin{array}{l}\text { peaty gley, } \\
\text { podzol, humic } \\
\text { iron podzol }\end{array}$ & $\begin{array}{l}\text { peaty gley, } \\
\text { podzol, } \\
\text { humic iron } \\
\text { podzol }\end{array}$ & $\begin{array}{l}\text { peat, iron } \\
\text { stagno-podzol }\end{array}$ & $\begin{array}{l}\text { peat, pelo- } \\
\text { stagnogley, } \\
\text { humic iron } \\
\text { podzol }\end{array}$ & $\begin{array}{l}\text { peat, humic } \\
\text { iron podzol }\end{array}$ & $\begin{array}{l}\text { brown forest } \\
\text { soil, skeletal } \\
\text { humic soil }\end{array}$ \\
\hline $\begin{array}{l}\text { Date last } \\
\text { inhabited }\end{array}$ & $\begin{array}{l}\text { Late } 19^{\text {th }} \\
\text { century }\end{array}$ & $\begin{array}{l}\text { Late } 19^{\text {th }} \\
\text { century }\end{array}$ & 1917 & 1938 & 1940 & 1940 \\
\hline $\begin{array}{l}\text { Settlement } \\
\text { type }\end{array}$ & Township & Township & $\begin{array}{l}\text { Tenanted } \\
\text { Farm }\end{array}$ & $\begin{array}{l}\text { Tenanted } \\
\text { Farm }\end{array}$ & Croft & Croft \\
\hline Layout & Byre house? & Byre house & Courtyard & Courtyard & Linear & Linear \\
\hline Construction & Clay mortar & Clay mortar & $\begin{array}{l}\text { Lime mortar } \\
\text { and plaster in } \\
\text { house. }\end{array}$ & $\begin{array}{l}\text { Lime mortar } \\
\text { in hose and } \\
\text { byre, plaster } \\
\text { in house. }\end{array}$ & $\begin{array}{l}\text { Clay mortar, } \\
\text { fireplace and } \\
\text { walls } \\
\text { patched with } \\
\text { lime. }\end{array}$ & $\begin{array}{l}\text { Clay mortar } \\
\text { internal shell } \\
\text { based } \\
\text { plaster. }\end{array}$ \\
\hline Main fuels & Peat and coal & $\begin{array}{l}\text { Peat and } \\
\text { coal }\end{array}$ & $\begin{array}{l}\text { Peat and } \\
\text { wood }\end{array}$ & $\begin{array}{l}\text { Peat, wood } \\
\text { and coal }\end{array}$ & Peat & $\begin{array}{l}\text { Turf and } \\
\text { coal }\end{array}$ \\
\hline Agriculture & $\begin{array}{l}\text { Mixed; oats, } \\
\text { bere, cattle, } \\
\text { sheep, poultry } \\
\text { and communal } \\
\text { pig, potatoes, } \\
\text { kale and } \\
\text { turnips. }\end{array}$ & $\begin{array}{l}\text { Mixed; } \\
\text { bere, oats, } \\
\text { potatoes, } \\
\text { turnips, } \\
\text { peas, lint, } \\
\text { cattle, sheep, } \\
\text { pigs and } \\
\text { poultry. }\end{array}$ & $\begin{array}{l}\text { Mixed; wheat, } \\
\text { barley and } \\
\text { oats, potatoes } \\
\text { and neeps, } \\
\text { Molinia and } \\
\text { bracken cut as } \\
\text { fodder; sheep, } \\
\text { cattle, pigs, } \\
\text { and poultry }\end{array}$ & $\begin{array}{l}\text { Mixed; } \\
\text { wheat, } \\
\text { barley, oats, } \\
\text { potatoes and } \\
\text { turnips, } \\
\text { cattle, sheep, } \\
\text { pigs and } \\
\text { poultry. }\end{array}$ & $\begin{array}{l}\text { Mixed, oats } \\
\text { and bear, } \\
\text { potatoes and } \\
\text { turnips, } \\
\text { cattle and } \\
\text { sheep, also } \\
\text { pigs and } \\
\text { poultry. }\end{array}$ & $\begin{array}{l}\text { Mixed, bere, } \\
\text { oats, kale } \\
\text { and potatoes, } \\
\text { few turnips, } \\
\text { cows, sheep, } \\
\text { poultry and } \\
\text { pigs, spade } \\
\text { cultivation }\end{array}$ \\
\hline Manure & $\begin{array}{l}\text { Byre and } \\
\text { domestic } \\
\text { waste, } \\
\text { commercial } \\
\text { fertiliser and } \\
\text { lime. }\end{array}$ & $\begin{array}{l}\text { Byre waste, } \\
\text { domestic } \\
\text { waste, turf } \\
\text { and lime }\end{array}$ & $\begin{array}{l}\text { Byre waste } \\
\text { particularly } \\
\text { bracken } \\
\text { bedding, and } \\
\text { lime. }\end{array}$ & $\begin{array}{l}\text { Byre waste } \\
\text { and lime }\end{array}$ & $\begin{array}{l}\text { Byre and } \\
\text { domestic } \\
\text { waste, and } \\
\text { commercial } \\
\text { fertiliser }\end{array}$ & $\begin{array}{l}\text { Byre waste, } \\
\text { domestic } \\
\text { waste, turf, } \\
\text { seaweed, } \\
\text { fish waste. }\end{array}$ \\
\hline Modern use & $\begin{array}{l}\text { Museum, } \\
\text { fields } \\
\text { cultivated. }\end{array}$ & $\begin{array}{l}\text { Grazing, } \\
\text { organic for } \\
\text { last } 5 \text { years }\end{array}$ & $\begin{array}{l}\text { Grazing, } \\
\text { possibly } \\
\text { limited liming }\end{array}$ & $\begin{array}{l}\text { Grazing no } \\
\text { fertiliser or } \\
\text { reseeding in } \\
\text { last } 10 \text { years. }\end{array}$ & $\begin{array}{l}\text { Rough } \\
\text { grazing, no } \\
\text { intervention }\end{array}$ & $\begin{array}{l}\text { Grazing, no } \\
\text { intervention. }\end{array}$ \\
\hline
\end{tabular}


Table 3: Mean element concentrations, $\mathrm{pH}$ and $\%$ loss on ignition in the functional areas of the six farm sites

\begin{tabular}{|c|c|c|c|c|c|c|c|c|c|c|c|c|c|c|c|c|}
\hline & HR & HS & BY & $\mathrm{MD}$ & GD & $\mathrm{RF}$ & $\mathrm{OF}$ & REF & HR & $\mathrm{HS}$ & BY & $\mathrm{MD}$ & GD & $\mathrm{RF}$ & OF & REF \\
\hline Ba $\left(\mathrm{mg} \mathrm{kg}^{-1}\right)$ & & & & & & & & & $\operatorname{Sr}(\mathrm{m}$ & $\left.\mathrm{kg}^{-1}\right)$ & & & & & & \\
\hline Auchindrain & & 52.6 & 31.0 & 255 & 31.9 & 51.7 & 91.4 & 40.3 & & 13.4 & 14.9 & 28.3 & 5.72 & 10.5 & 22.3 & 8.78 \\
\hline Balnreich & 129 & 54.2 & 41.0 & & 35.7 & 22.0 & 24.8 & 12.2 & 24.3 & 8.57 & 6.24 & & 6.93 & 5.42 & 5.73 & 4.52 \\
\hline Cwm Eunant & 320 & 338 & 68.3 & 51.4 & 45.7 & 28.5 & 22.1 & 26.5 & 97.9 & 72.1 & 24.3 & 13.6 & 3.84 & 4.07 & 2.68 & 4.46 \\
\hline Far House & 28.0 & 194 & 97.2 & 71.5 & 18.2 & 23.0 & 26.4 & 52.1 & 159 & 85.0 & 62.6 & 24.1 & 1.17 & 2.27 & 5.02 & 4.09 \\
\hline Grumby & 204 & 91.7 & 147 & 135 & 146 & 92.5 & 24.7 & 24.7 & 138 & 50.2 & 50.9 & 21.0 & 28.1 & 19.9 & 14.0 & 14.0 \\
\hline Olligarth & 91.7 & 253 & 194 & 157 & 142 & 109 & 19.3 & 63.9 & 192 & 92.8 & 45.4 & 36.9 & 43.6 & 25.9 & 14.5 & 27.0 \\
\hline Ca $\left(\mathrm{g} \mathrm{kg}^{-1}\right)$ & & & & & & & & & $\operatorname{Zn}(\mathrm{n}$ & $\left.\mathbf{k g}^{-1}\right)$ & & & & & & \\
\hline Auchindrain & & 1.94 & 3.11 & 5.08 & 1.19 & 2.33 & 3.16 & 1.31 & & 86.9 & 377 & 600 & 36.7 & 50.5 & 44.3 & 28.2 \\
\hline Balnreich & 4.08 & 1.89 & 1.26 & & 1.77 & 2.20 & 1.24 & 1.53 & 92.2 & 41.5 & 30.2 & & 52.7 & 24.6 & 53.8 & 24.2 \\
\hline Cwm Eunant & 84.3 & 57.9 & 8.33 & 4.01 & 0.980 & 1.04 & 0.909 & 0.703 & 441 & 272 & 320 & 209 & 80.8 & 80.1 & 59.7 & 23.6 \\
\hline Far House & 76.2 & 64.2 & 30.6 & 3.32 & 0.342 & 1.16 & 2.14 & 0.631 & 1020 & 136 & 225 & 83.0 & 30.2 & 33.4 & 51.0 & 35.4 \\
\hline Grumby & 73.2 & 9.04 & 7.99 & 2.54 & 2.58 & 2.00 & 0.866 & 0.866 & 102 & 446 & 101 & 115 & 67.1 & 49.2 & 14.0 & 14.0 \\
\hline Olligarth & 23.0 & 7.23 & 1.96 & 1.29 & 1.74 & 0.938 & 0.769 & 1.39 & 1210 & 854 & 236 & 219 & 71.2 & 34.2 & 15.3 & 28.1 \\
\hline$P\left(\mathrm{~g} \mathrm{~kg}^{-1}\right)$ & & & & & & & & & $\mathbf{P b}(\mathrm{m}$ & $\left.\mathrm{kg}^{-1}\right)$ & & & & & & \\
\hline Auchindrain & & 1.54 & 2.82 & 2.19 & 1.87 & 0.791 & 0.799 & 0.951 & & 136 & 61.6 & 235 & 60.1 & 26.7 & 18.6 & 32.4 \\
\hline Balnreich & 1.06 & 1.54 & 2.05 & & 1.16 & 0.634 & 0.674 & 0.323 & 69.1 & 73.1 & 41.8 & & 17.6 & 12.7 & 18.0 & 20.3 \\
\hline Cwm Eunant & 1.63 & 1.39 & 1.21 & 1.43 & 1.74 & 1.34 & 1.08 & 0.557 & 1490 & 3150 & 86.5 & 182 & 118 & 55.2 & 56.2 & 84.4 \\
\hline Far House & 2.50 & 0.820 & 6.15 & 2.55 & 0.583 & 0.404 & 1.06 & 1.28 & 1690 & 246 & 69.3 & 117 & 52.1 & 59.4 & 157 & 117 \\
\hline Grumby & 1.25 & 1.30 & 2.57 & 1.66 & 1.50 & 1.09 & 0.990 & 0.990 & 367 & 115 & 29.9 & 29.7 & 35.6 & 28.8 & 24.8 & 24.8 \\
\hline Olligarth & 5.83 & 4.87 & 3.10 & 2.73 & 1.98 & 1.32 & 0.455 & 0.473 & 179 & 203 & 99.9 & 232 & 71.3 & 58.5 & 25.4 & 60.8 \\
\hline pH & & & & & & & & & $\%$ los & on igni & $\overline{\text { on }(w)}$ & & & & & \\
\hline Auchindrain & & 4.3 & 6.0 & 5.1 & 4.1 & 5.1 & 5.3 & 4.8 & & 17 & 4 & 14 & 14 & 14 & 12 & 31 \\
\hline Balnreich & 5.3 & 4.4 & 4.1 & & 5.0 & 5.6 & 5.1 & 4.8 & 18 & 22 & 13 & & 9 & 9 & 8 & 17 \\
\hline Cwm Eunant & 7.4 & 7.5 & 5.8 & 5.5 & 4.3 & 4.8 & 4.0 & 4.4 & 16 & 17 & 20 & 15 & 11 & 10 & 13 & 23 \\
\hline Far House & 7.2 & 7.5 & 7.1 & 5.6 & 4.3 & 5.2 & 4.0 & 3.5 & 21 & 10 & 29 & 15 & 7 & 6 & 50 & 28 \\
\hline Grumby & 7.5 & 4.5 & 5.8 & 5.0 & 4.7 & 4.7 & 4.0 & 4.0 & 15 & 48 & 13 & 12 & 17 & 13 & 40 & 40 \\
\hline Olligarth & 6.3 & 6.5 & 4.8 & 4.2 & 5.1 & 5.1 & 3.8 & 3.9 & 39 & 14 & 19 & 24 & 16 & 13 & 44 & 50 \\
\hline
\end{tabular}

HR Hearth; HS House; BY Byre; MD Midden; GD Garden; RF Arable; OF Outfield; REF Reference 
Table 2: Mean element concentrations $\left(\mathrm{mg} \mathrm{kg}^{-1}\right)$ in the reference soils at each farm.

\begin{tabular}{lllllll}
\hline & Auchindrain & Balnreich & $\begin{array}{l}\text { Cwm } \\
\text { Eunant }\end{array}$ & Far House & Grumby & Olligarth \\
\hline $\mathrm{Ca}$ & 1310 & 1530 & 703 & 631 & 866 & 1390 \\
$\mathrm{Co}$ & 4.41 & 1.75 & 15.6 & 2.28 & .969 & .285 \\
$\mathrm{Cu}$ & 6.97 & 7.64 & 6.94 & 19.9 & 2.34 & 7.78 \\
$\mathrm{Mn}$ & 207 & 68.6 & 1340 & 24.8 & 53.8 & 20.5 \\
$\mathrm{P}$ & 951 & 323 & 557 & 1290 & 990 & 473 \\
$\mathrm{~Pb}$ & 32.4 & 20.3 & 84.4 & 117 & 24.8 & 60.8 \\
$\mathrm{Ti}$ & 572 & 315 & 12.0 & 27.7 & 154 & 80.8 \\
\hline
\end{tabular}

Table 4: Analysis of Variance F values for site and functional area effects (all significant at $\mathrm{p}<.05)$

\begin{tabular}{|c|c|c|c|c|c|c|c|c|c|c|c|}
\hline & DF & $\mathrm{P}$ & $\mathrm{Ca}$ & $\mathrm{Zn}$ & $\mathrm{Cu}$ & $\mathrm{Pb}$ & $\mathrm{Mn}$ & $\mathrm{Fe}$ & $\mathrm{Ni}$ & $\mathrm{V}$ & $\mathrm{Ti}$ \\
\hline Site & 3 & 25.5 & 78.2 & 53.7 & 103 & 228 & 206 & 422 & 329 & 43.4 & 635 \\
\hline Functional area & 8 & 129 & 705 & 256 & 74.5 & 153 & 112 & 100 & 158 & 63.7 & 18.7 \\
\hline $\begin{array}{l}\text { Site*Functional } \\
\text { area }\end{array}$ & 19 & 53.1 & 57.3 & 24.5 & 26.3 & 23.1 & 18.5 & 30.1 & 40.6 & 58.6 & 8.29 \\
\hline
\end{tabular}

Table 5: Within-group correlations between discriminating variables (log of element soil concentrations) and discriminant functions.

\begin{tabular}{lrrrr}
\hline & \multicolumn{4}{c}{ Function } \\
& $\mathbf{1}$ & $\mathbf{2}$ & $\mathbf{3}$ & $\mathbf{4}$ \\
\hline \% of variance & 61 & 23 & 7.5 & 4.6 \\
\hline $\mathrm{Al}$ & 0.01 & -0.17 & 0.00 & $\mathbf{0 . 3 4}$ \\
$\mathrm{Ba}$ & $\mathbf{0 . 1 9}$ & $\mathbf{- 0 . 2 6}$ & $\mathbf{0 . 2 0}$ & -0.09 \\
$\mathrm{Ca}$ & $\mathbf{0 . 6 0}$ & -0.08 & -0.13 & 0.14 \\
$\mathrm{Cr}$ & 0.08 & $\mathbf{- 0 . 2 0}$ & $\mathbf{- 0 . 2 2}$ & $\mathbf{0 . 2 5}$ \\
$\mathrm{Cu}$ & $\mathbf{0 . 1 9}$ & -0.15 & 0.01 & 0.07 \\
$\mathrm{Li}$ & -0.01 & -0.12 & -0.07 & $\mathbf{0 . 2 4}$ \\
$\mathrm{Mg}$ & 0.06 & $\mathbf{- 0 . 2 0}$ & $\mathbf{- 0 . 2 3}$ & $\mathbf{0 . 1 8}$ \\
$\mathrm{Mn}$ & 0.15 & $\mathbf{- 0 . 2 9}$ & -0.04 & $\mathbf{0 . 2 8}$ \\
$\mathrm{Na}$ & 0.12 & $\mathbf{0 . 2 3}$ & 0.00 & 0.13 \\
$\mathrm{P}$ & $\mathbf{0 . 1 9}$ & $\mathbf{- 0 . 2 8}$ & $\mathbf{- 0 . 2 7}$ & 0.13 \\
$\mathrm{~Pb}$ & $\mathbf{0 . 2 3}$ & 0.11 & $\mathbf{0 . 3 3}$ & $\mathbf{0 . 1 8}$ \\
$\mathrm{Sr}$ & $\mathbf{0 . 3 5}$ & -0.09 & 0.01 & 0.10 \\
$\mathrm{~V}$ & 0.08 & -0.10 & -0.07 & $\mathbf{0 . 3 7}$ \\
$\mathrm{Y}$ & 0.10 & -0.09 & $\mathbf{0 . 2 3}$ & 0.06 \\
$\mathrm{Zn}$ & $\mathbf{0 . 4 5}$ & $\mathbf{- 0 . 2 3}$ & -0.00 & 0.09 \\
\hline Modelled cases correctly classified & $83.2 \%$ \\
Independent cases correctly classified & $75.4 \%$ \\
\hline \multicolumn{5}{c}{}
\end{tabular}


Table 6: Canonical discriminant functions at functional area group means

\begin{tabular}{lcrrr}
\hline & \multicolumn{4}{c}{ Function } \\
\cline { 2 - 5 } & \multicolumn{1}{c}{$\mathbf{1}$} & $\mathbf{2}$ & \multicolumn{1}{l}{$\mathbf{3}$} & \multicolumn{1}{c}{$\mathbf{4}$} \\
\hline Hearth & 7.12 & 3.13 & 0.41 & 2.36 \\
House & 5.25 & -0.04 & 0.94 & -1.07 \\
Byre & 2.47 & -1.65 & -1.59 & -0.44 \\
Midde n & -0.05 & -1.72 & 0.14 & -0.49 \\
Kailyard & -2.09 & -1.49 & 0.66 & 0.56 \\
In-field & -2.24 & -0.87 & 0.24 & 0.71 \\
Out-field & -2.18 & 2.70 & -1.71 & -0.18 \\
Reference soils & -2.73 & 3.19 & 1.75 & -1.07 \\
\hline
\end{tabular}

Table 7: Univariate ANOVA p-values of reference materials for between site differences

\begin{tabular}{lcccccccccc}
\hline & $\mathrm{P}$ & $\mathrm{Ca}$ & $\mathrm{Zn}$ & $\mathrm{Cu}$ & $\mathrm{Pb}$ & $\mathrm{Mn}$ & $\mathrm{Fe}$ & $\mathrm{Ni}$ & $\mathrm{V}$ & $\mathrm{Ti}$ \\
\hline Bracken & $<. \mathbf{0 0 0}$ & $\mathbf{. 0 0 1}$ & .857 & .138 & .822 & $<. \mathbf{0 0 0}$ & $\mathbf{. 0 0 2}$ & $<. \mathbf{0 0 0}$ & .075 & $\mathbf{. 0 1 4}$ \\
Dung & $\mathbf{. 0 0 1}$ & $\mathbf{. 0 0 3}$ & $<. \mathbf{0 0 0}$ & $<. \mathbf{0 0 0}$ & .452 & $\mathbf{. 0 1 8}$ & .425 & $\mathbf{. 0 0 1}$ & .504 & .272 \\
Lime & $\mathbf{. 0 2 2}$ & .083 & .632 & .134 & .273 & .450 & .051 & .103 & $\mathbf{. 0 4 6}$ & .069 \\
mortar & & & & & & & & & & \\
Peat & .194 & .172 & .481 & .330 & .233 & .266 & .432 & .474 & .134 & .244 \\
Turf & $\mathbf{. 0 4 5}$ & $\mathbf{. 0 4 4}$ & $\mathbf{. 0 2 5}$ & .296 & .064 & $\mathbf{. 0 0 9}$ & .074 & .147 & .116 & .875 \\
\hline
\end{tabular}

Bold type indicates significant p-value at 0.05 level.

Table 8: Multivariate ANOVA $\mathrm{F}$ values for between site and between material differences.

\begin{tabular}{lccccccccccc}
\hline & $\mathrm{DF}$ & $\mathrm{P}$ & $\mathrm{Ca}$ & $\mathrm{Zn}$ & $\mathrm{Cu}$ & $\mathrm{Pb}$ & $\mathrm{Mn}$ & $\mathrm{Fe}$ & $\mathrm{Ni}$ & $\mathrm{V}$ & $\mathrm{Ti}$ \\
\hline Site & 5 & $\mathbf{3 . 5 9}$ & $\mathbf{1 0 . 4}$ & .531 & .635 & 1.16 & 1.75 & .615 & .956 & 2.78 & .907 \\
Material & 6 & $\mathbf{9 0 1}$ & $\mathbf{2 8 1}$ & 1.33 & $\mathbf{4 . 9 2}$ & $\mathbf{4 . 4 5}$ & $\mathbf{4 1 . 7}$ & $\mathbf{3 . 1 1}$ & 1.76 & $\mathbf{9 . 6 8}$ & 1.96 \\
Site* Material & 19 & $\mathbf{2 . 6 4}$ & $\mathbf{7 . 9}$ & 1.07 & 1.35 & 1.61 & .930 & 1.18 & $\mathbf{1 . 8 3}$ & 1.35 & 1.57 \\
\hline Bold type indicates significant & p-value & & & & & & &
\end{tabular}

Bold type indicates significant p-value at 0.05 level. 
Table 9: Summary of relative element distributions in soil thin sections as mapped using SEM-WDX.

\begin{tabular}{|c|c|c|c|c|c|c|}
\hline Context & $\mathbf{F e}$ & $\mathbf{C a}$ & $\mathbf{P}$ & Zn & $\mathbf{S r}$ & $\mathrm{Cu}$ \\
\hline Hearth & $\begin{array}{l}\text { High - Carbonised } \\
\text { fragments. } \\
\text { Low - Mineral grains } \\
\text { and rock fragments and } \\
\text { charcoal. }\end{array}$ & $\begin{array}{l}\text { High -Carbonised } \\
\text { particles and } \\
\text { occasional mineral } \\
\text { grains }\end{array}$ & $\begin{array}{l}\text { High - General } \\
\text { carbonised } \\
\text { trampled layer } \\
\text { Lower below } \\
\text { trampled layer }\end{array}$ & $\begin{array}{l}\text { High - Single mineral } \\
\text { grains } \\
\text { Moderate - Igneous rock } \\
\text { fragments } \\
\text { Low- Organic matrix }\end{array}$ & $\begin{array}{l}\text { High - Mineral and } \\
\text { rock fragments } \\
\text { Low - Carbonised } \\
\text { material }\end{array}$ & $\begin{array}{l}\text { High - Single mineral } \\
\text { grains } \\
\text { Moderate - Igneous rock } \\
\text { fragments } \\
\text { Low- Organic matrix }\end{array}$ \\
\hline Byre & $\begin{array}{l}\text { High - Mineral } \\
\text { Moderate - bone } \\
\text { Low - Charcoal and coal }\end{array}$ & $\begin{array}{l}\text { High - Bone } \\
\text { Moderate - Soil } \\
\text { matrix } \\
\text { Low coal and } \\
\text { charcoal }\end{array}$ & $\begin{array}{l}\text { High - Bone } \\
\text { fragments } \\
\text { Low - Charcoal } \\
\text { and coal }\end{array}$ & $\begin{array}{l}\text { High - Bone fragments } \\
\text { and mineral } \\
\text { Moderate - Igneous rock } \\
\text { fragments } \\
\text { Low - Charcoal and coal }\end{array}$ & $\begin{array}{l}\text { High - Bone } \\
\text { fragments and } \\
\text { Igneous rock } \\
\text { fragments } \\
\text { Low - Charcoal } \\
\text { and coal }\end{array}$ & $\begin{array}{l}\text { High - Bone fragments } \\
\text { and mineral } \\
\text { Moderate - Igneous rock } \\
\text { fragments } \\
\text { Low - Charcoal and coal }\end{array}$ \\
\hline Kailyard & $\begin{array}{l}\text { High - Carbonised } \\
\text { particles and mineral } \\
\text { grains } \\
\text { Moderate - Matrix and } \\
\text { carbonised grains } \\
\text { Low - Mineral grains } \\
\text { and carbonised particles }\end{array}$ & $\begin{array}{l}\text { High - Carbonised } \\
\text { particles } \\
\text { Moderate - organic } \\
\text { matrix } \\
\text { Low - Quartz } \\
\text { grains }\end{array}$ & $\begin{array}{l}\text { High - Mineral } \\
\text { grains } \\
\text { Moderate - Organic } \\
\text { matrix and } \\
\text { carbonised particles } \\
\text { Low- Quartz grains } \\
\text { and carbonised } \\
\text { particles }\end{array}$ & No data & No data & No data \\
\hline Arable/rig & No data & $\begin{array}{l}\text { High-Carbonised } \\
\text { particles } \\
\text { Moderate-Matrix } \\
\text { and carbonised } \\
\text { particles } \\
\text { Low- Rock } \\
\text { fragments }\end{array}$ & $\begin{array}{l}\text { High - Carbonised } \\
\text { particles } \\
\text { Low- Mineral } \\
\text { grains and } \\
\text { carbonised particles }\end{array}$ & No data & No data & No data \\
\hline Grazing/outfield & No data & $\begin{array}{l}\text { High - Mineral } \\
\text { grains } \\
\text { Low - Quartz } \\
\text { grains }\end{array}$ & $\begin{array}{l}\text { Moderate - Organic } \\
\text { matrix } \\
\text { Low - Mineral and } \\
\text { rock fragments }\end{array}$ & No data & No data & No data \\
\hline
\end{tabular}


Table 10: Summary findings of archaeologically correlated element patterns from previous multi-element soil analyses.

\begin{tabular}{|c|c|c|c|c|c|c|c|c|c|c|c|c|c|c|c|c|c|}
\hline Reference & Age & Type & Location & $\mathrm{P}$ & $\mathrm{Pb}$ & $\mathrm{Zn}$ & $\mathrm{Cu}$ & $\mathrm{Cd}$ & $\mathrm{Mg}$ & $\mathrm{Mn}$ & $\mathrm{Ca}$ & $\mathrm{Ti}$ & $\mathrm{Rb}$ & $\mathrm{Sr}$ & $\mathrm{K}$ & $\mathrm{Ba}$ & Interpretation \\
\hline $\begin{array}{l}\text { Aston et al. } \\
1998\end{array}$ & Roman & Settlement & Somerset & $\checkmark$ & $\checkmark$ & $\checkmark$ & $\checkmark$ & $\checkmark$ & & $\checkmark$ & & & & & & & $\begin{array}{l}\text { Mn associated with burning } \\
\text { and waterlogging. }\end{array}$ \\
\hline $\begin{array}{l}\text { Bintliff et al. } \\
1992\end{array}$ & Various & Various & Greece & & $\checkmark$ & $*$ & $\checkmark$ & & & * & & & & & & & $\begin{array}{l}\mathrm{Cu} \text { and } \mathrm{Pb} \text { correlate with } \\
\text { archaeology. }\end{array}$ \\
\hline $\begin{array}{l}\text { Konrad et al. } \\
1983\end{array}$ & $\begin{array}{l}\text { Palaeo- } \\
\text { indian }\end{array}$ & Settlement & Maine, US & $\checkmark$ & & & & & $\checkmark$ & & $\checkmark$ & & & & & & $\begin{array}{l}\mathrm{Mg} \text { associated with hearth, } \\
\mathrm{P} \text { and } \mathrm{Mg} \text { habitation. }\end{array}$ \\
\hline $\begin{array}{l}\text { Dunnell, } \\
1993\end{array}$ & $\begin{array}{l}\text { Palaeo- } \\
\text { Indian }\end{array}$ & Various & US & $\checkmark$ & & & & & & & & & $\checkmark$ & $\checkmark$ & & & $\begin{array}{l}\mathrm{P}, \mathrm{K} \text {, and } \mathrm{Ca} \text { in soil affect } \\
\text { vegetation. }\end{array}$ \\
\hline $\begin{array}{l}\text { Da Costa \& } \\
\text { Kern, } 1999\end{array}$ & $\begin{array}{l}\text { Palaeo- } \\
\text { Indian }\end{array}$ & Black earths & Brazil & $\checkmark$ & $*$ & $\checkmark$ & $\checkmark$ & $*$ & $\checkmark$ & $\checkmark$ & $\checkmark$ & & & $\checkmark$ & & $\checkmark$ & $\begin{array}{l}\mathrm{P} \text { and } \mathrm{Mg} \text { meat; } \mathrm{Mn}, \mathrm{Cu} \text { and } \\
\mathrm{Zn} \text { vegetable. }\end{array}$ \\
\hline $\begin{array}{l}\text { Kristiansen, } \\
2001\end{array}$ & BA/IA & Cultivation & Denmark & $\checkmark$ & & & & & $*$ & & $*$ & & & & $*$ & & $\begin{array}{l}\text { Leaching of imported } \\
\text { elements. }\end{array}$ \\
\hline $\begin{array}{l}\text { Linderholm } \\
\text { \& Lundberg } \\
1994\end{array}$ & BA & $\begin{array}{l}\text { Settlement } \\
\text { Cultivation }\end{array}$ & Sweden & $\checkmark$ & $*$ & $\checkmark$ & $\checkmark$ & & & $\checkmark$ & $\checkmark$ & & & & & & $\begin{array}{l}\mathrm{Mn}, \mathrm{Cu}, \mathrm{Zn}, \mathrm{Ca} \text { associated } \\
\text { with features. }\end{array}$ \\
\hline $\begin{array}{l}\text { Wells et al. } \\
2000\end{array}$ & Mayan & Settlement & Guatemala & $\checkmark$ & & & $\checkmark$ & $\checkmark$ & & $\checkmark$ & & & & & & & $\begin{array}{l}\text { Paint, craft wastes, and } \\
\text { kitchen wates. }\end{array}$ \\
\hline Middleton \& & Modern & House floors & Mexico & $\checkmark$ & & $\checkmark$ & & & $*$ & $*$ & $\checkmark$ & $\checkmark$ & & $\checkmark$ & $\checkmark$ & $*$ & Functional areas very \\
\hline Price, 1996 & Ancient & & Canada & & & & & & & & & & & & & & different. \\
\hline James, 1999 & Roman & Tile spread & Greece & $\checkmark$ & $\checkmark$ & $\checkmark$ & $\checkmark$ & $\checkmark$ & $*$ & * & $\checkmark$ & & & & $\checkmark$ & & $\begin{array}{l}\text { High } \mathrm{Pb}, \mathrm{Cu}, \mathrm{Zn}, \mathrm{K}, \mathrm{Mn}, \mathrm{Ca} \text {, } \\
\text { in artefact spreads. }\end{array}$ \\
\hline $\begin{array}{l}\text { Lewis et al. } \\
1993\end{array}$ & Roman & Villa & Rome & $\checkmark$ & $\checkmark$ & $\checkmark$ & $\checkmark$ & & & $\checkmark$ & & & & & & & $\begin{array}{l}\mathrm{Pb} \text {, and } \mathrm{Zn} \text { high in and near } \\
\text { buildings. }\end{array}$ \\
\hline $\begin{array}{l}\text { Griffith, } \\
1981\end{array}$ & $\begin{array}{l}\text { Palaeo- } \\
\text { Indian }\end{array}$ & Settlement & Canada & $\checkmark$ & & & & & $\checkmark$ & & $*$ & & & & $*$ & & $\begin{array}{l}\text { Mg most useful at showing } \\
\text { settlement. }\end{array}$ \\
\hline $\begin{array}{l}\text { Entwistle et } \\
\text { al. } 2000\end{array}$ & $\begin{array}{l}\text { Post- } \\
\text { Med. }\end{array}$ & Settlement & Skye & $\checkmark$ & $*$ & $*$ & $*$ & & $*$ & & $\checkmark$ & & $\checkmark$ & & $\checkmark$ & $\checkmark$ & $\begin{array}{l}\mathrm{Sr}, \mathrm{Ca}-\text { field; } \mathrm{K}, \mathrm{Th}, \mathrm{Rb}, \mathrm{Cs} \text {, } \\
\text { habitation. }\end{array}$ \\
\hline $\begin{array}{l}\text { Pierce et al. } \\
1998\end{array}$ & $\begin{array}{l}\text { Modern } \\
\text { Ancient }\end{array}$ & Fuel Ash & Colorado & & $*$ & $\checkmark$ & $\checkmark$ & $\checkmark$ & $\checkmark$ & $\checkmark$ & $\checkmark$ & $\checkmark$ & & $\checkmark$ & $\checkmark$ & $\checkmark$ & \\
\hline
\end{tabular}


Figure 1: Tamhanes post-hoc pairwise comparisons of site and functional area differences, graphs show 95\% confidence intervals normalised against the Cwm Eunant byre samples.

Figure 2: Mean element concentrations for selected reference materials.

Figure 3: Microprobe maps showing the effect of bone and charcoal on element distributions. 
Figure 1

Click here to download high resolution image

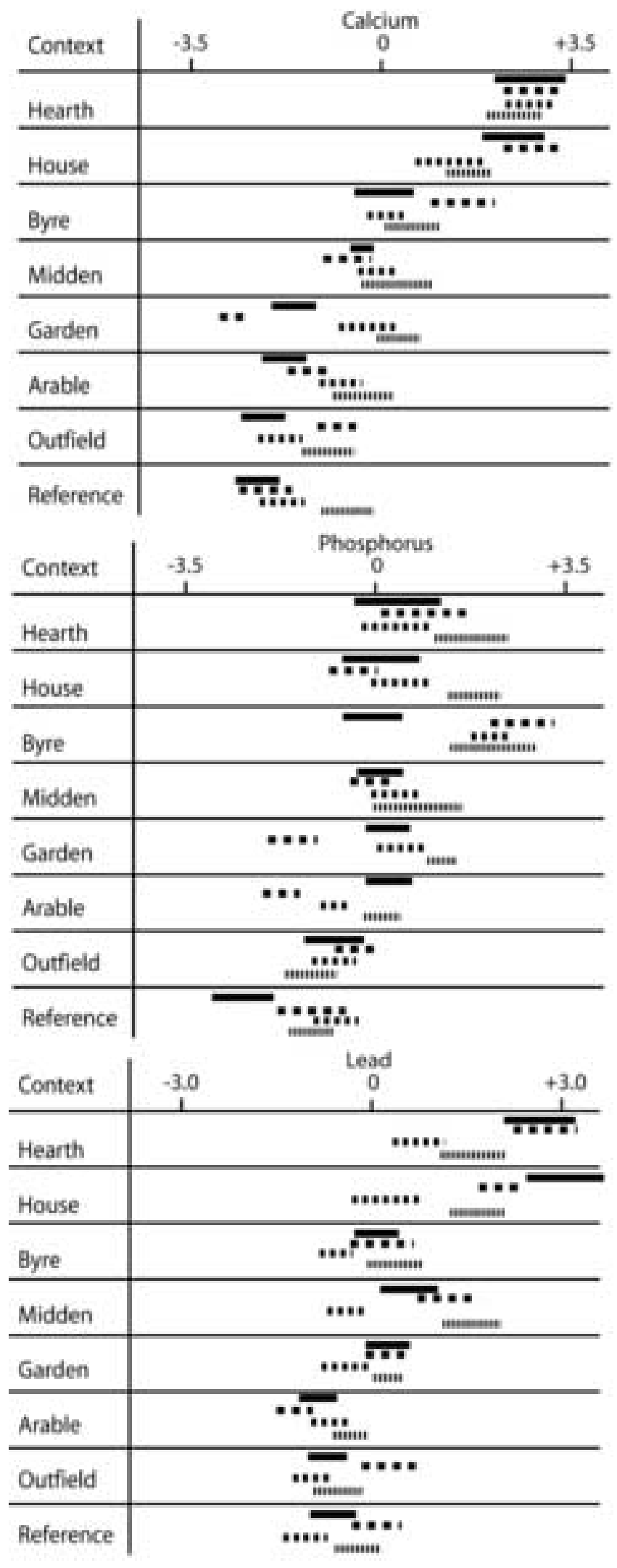

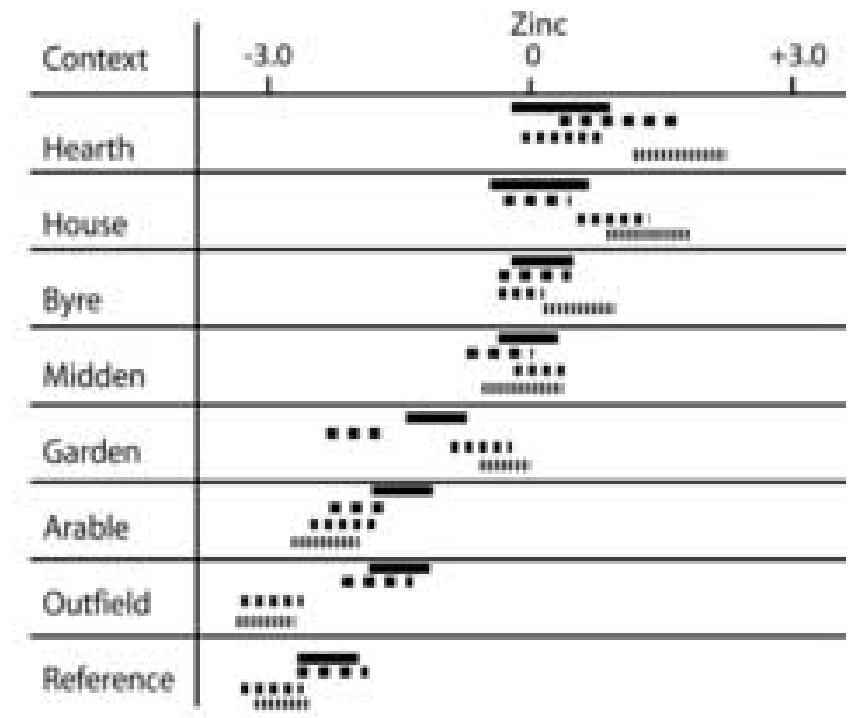

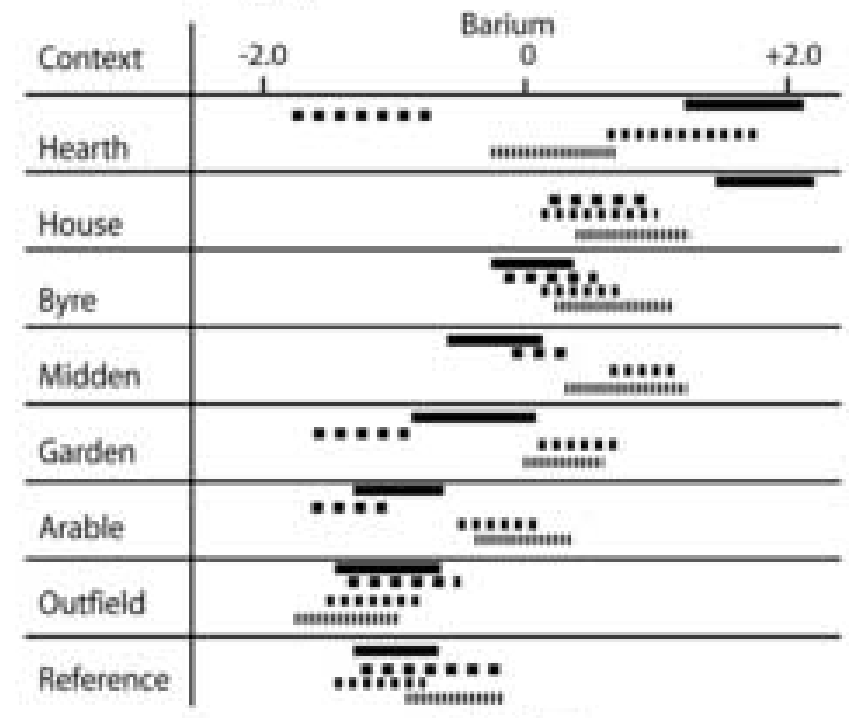

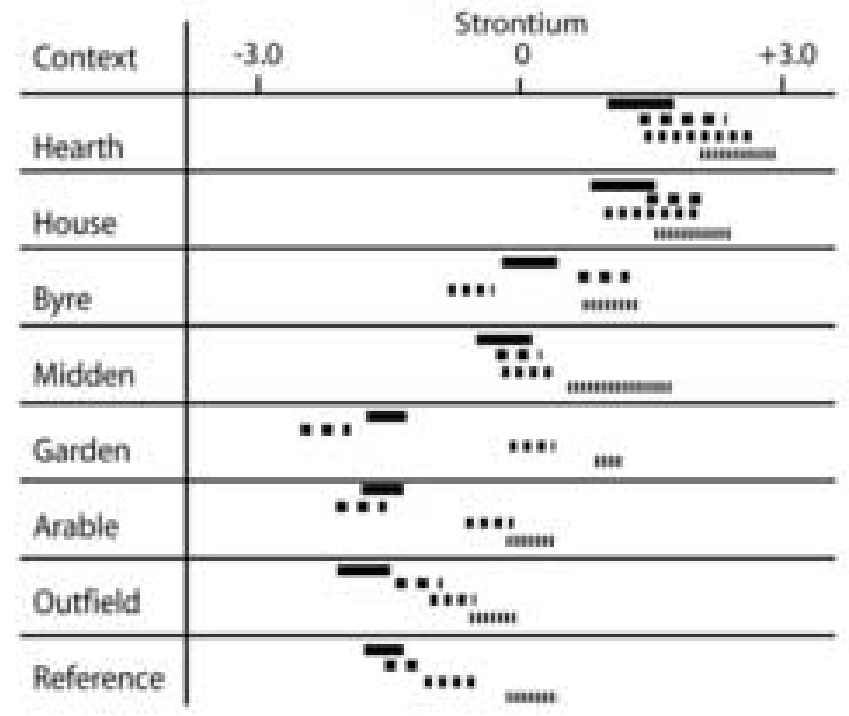

Cwm Eunant ......... Grumby $=-\infty$. Far House миминаме Olligarth 
Figure 2
Click here to download high resolution image
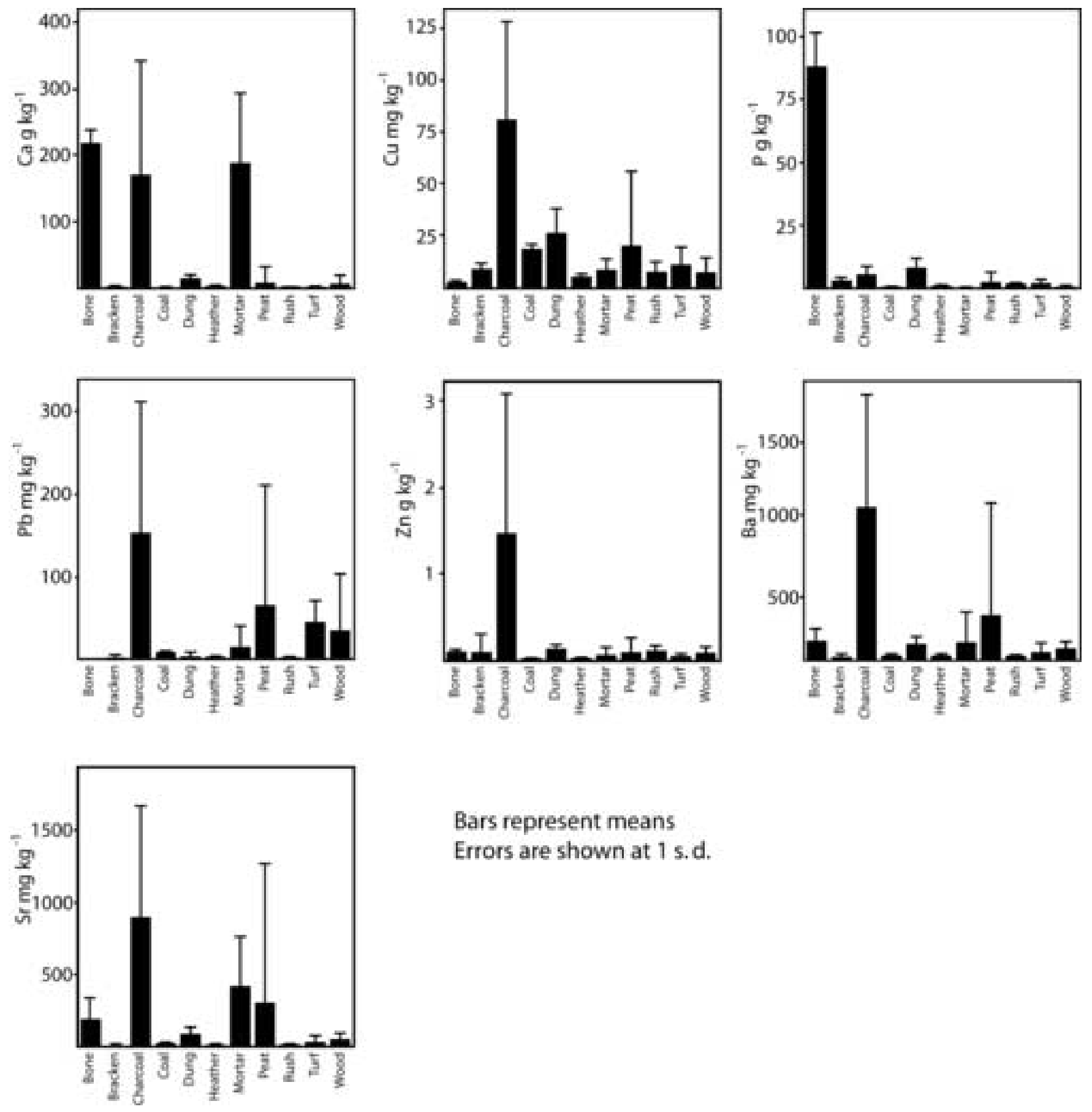

Bars represent means

Errors are shown at 1 s.d. 
Figure 3
Click here to download high resolution image

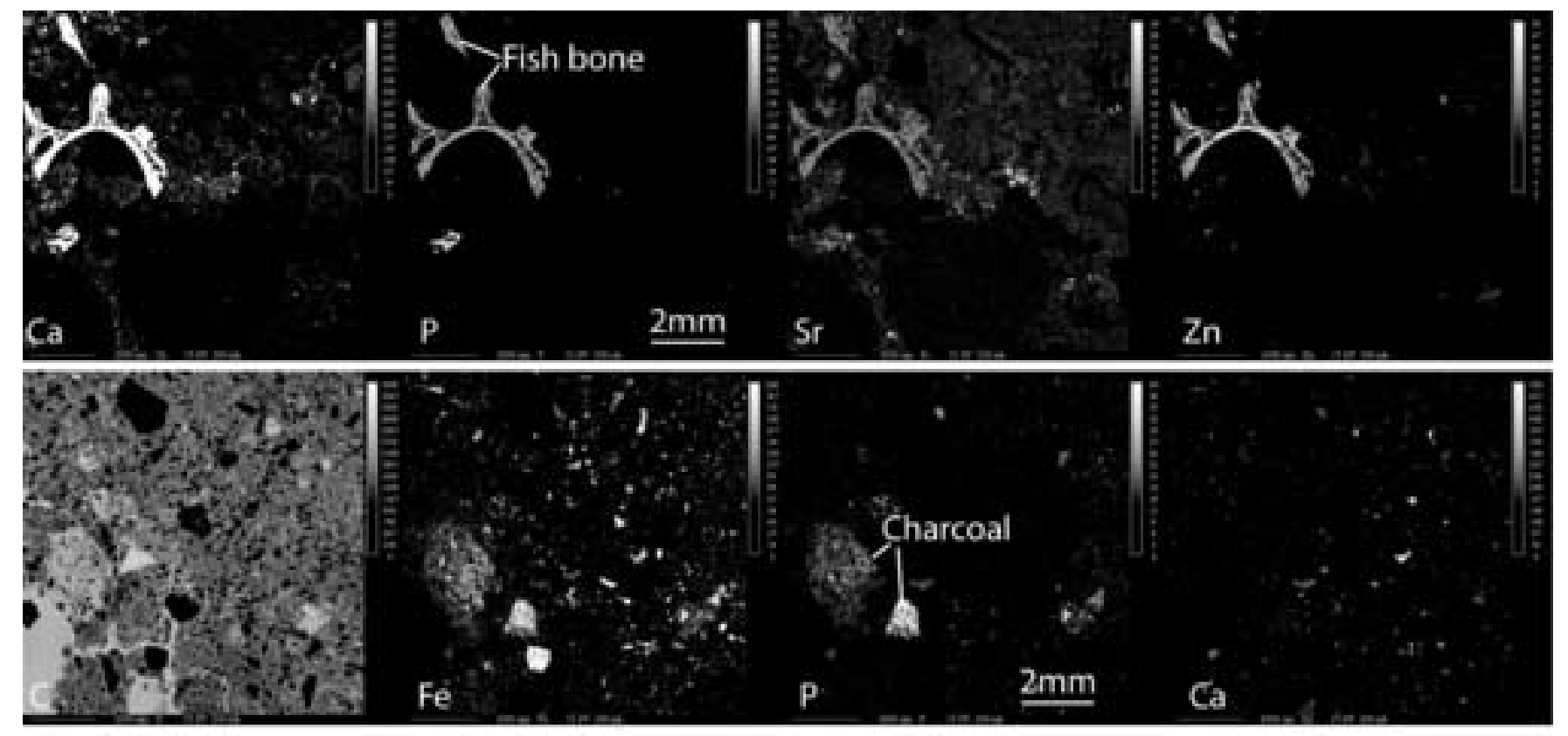

